\title{
Andrew Gray, M.A., LL.D., F.R.S.
}

ANDREw GRAy was born on the 2nd of July 1847, at Lochgelly, Fifeshire, and spent his youth in his native village. The educational opportunities which the village provided were somewhat meagre, but he acquired a good knowledge of English and Mathematics and made some progress in Latin and Greek. At that time the favourite textbook in arithmetic was James Gray's Introduction to Arithmetic. After working through "The Gray," as the book was usually called-the name being a synonym for "arithmetic," just as "Euclid" was for "geometry,"-he was promoted to Davidson's Practical Mathematics; but in mastering this more advanced textbook he was left to a considerable extent to his own resources. These books are now almost unknown, but, in spite of their defects, they abounded in exercises of a practical kind that aroused the interest of a studious boy; and the custom of leaving the pupil to work by himself, and of giving help only after complete failure on his part, developed a spirit of independence that was afterwards of decided value for higher research.

Some years elapsed after Gray left school before he entered the University. Part of this period was spent in Edinburgh, and there he made the acquaintance of James Pryde, who is now perhaps best known as the editor of Chambers's Mathematical Tables. Pryde was one of the teachers in the old Watt Institution; Gray was an eager student, and soon attracted his teacher's attention. An invitation to Pryde's house was followed by frequent visits and by the loan of books on higher mathematics, among them Lagrange's Mécanique Analytique. The encouragement thus given, which was always gratefully remembered, was perhaps the most important factor in determining him to undertake a University course, and in 1872 he matriculated in the University of Glasgow as a student in the Faculty of Arts.

During his undergraduate course, like many other students at that time, he was obliged to devote a part of his day to teaching; but he overcame all obstacles, took a good position in all his classes, and distinguished himself specially in Mathematics and Natural Philosophy, finally graduating in 1876 as M.A., with Honours in these two subjects. The classes, outside those of Mathematics and Natural Philosophy, which he found most congenial were those of Latin and Greek, and he always retained an interest in these languages. There was no surer way of irritating him 
than to suggest that an expert in physical science could not be expected to have any knowledge or appreciation of the ancient classics.

In 1875 he was asked by Sir William Thomson to become his private assistant, and he remained with him in this capacity till 1880, when he was appointed official class assistant. From this date onwards his work lay in teaching and research in the department of Natural Philosophy.

When the University College of North Wales was established in 1884 Gray was appointed Professor of Physics. Of the other professors appointed at the same time, two, Henry Jones and James J. Dobbie, were also Glasgow graduates; another professor, not a Glasgow graduate, was G. B. Mathews, and with these three his friendship was peculiarly intimate. Though they did not remain long together at Bangor, the intimacy was constantly renewed during the vacations. Gray survived the others, and he felt their loss very keenly.

The Bangor professorship provided the opportunity for testing Gray's powers. He soon made for himself a name and position. His sound judgment, his business capacity, and his untiring industry proved to be invaluable in the adjustment of the many difficulties that beset a new college. In the wider field of University extension and secondary education he was also an active worker, and he took a leading part in the foundation of the County School for Girls at Bangor.

In 1899 Lord Kelvin retired from the Chair of Natural Philosophy in Glasgow, and Gray was appointed his successor. It was a signal honour to be selected to fill the Chair which Kelvin had occupied for fifty-three years, but Gray amply justified the choice of the University Court. In the latter part of this Notice reference is made to the development of the department under his charge. It is perhaps sufficient to say here that the qualities which had distinguished his Bangor professorship were brought into even greater prominence in Glasgow. He was regular in attendance at the meetings of the Faculties and the Senate and helpful in the discussion of all matters that came before them. For eight years he was one of the Senate's representatives on the University Court, and during that period he took an active part in the many developments that have been so marked a feature of recent years. Colleagues frequently sought his advice and gratefully acknowledged the kindness with which he helped them in their difficulties.

His activities, however, were not limited by the demands of the University. He delivered many lectures to learned societies and to audiences of electrical engineers and of shipbuilders. His University Oration in memory of Lord Kelvin was afterwards expanded, and was 
published in 1908 with the title The Life and Work of Lord Kelvin. He was a Member of Council of this Society from 1903 to 1906, and a Vice-President from 1906 to 1909. At the Bournemouth meeting of the British Association in 1919 he was President of Section A.

Gray had a fine physique, and for many years enjoyed excellent health; but in 1909 he had a serious illness from which he never fully recovered, though still able for the duties of the Chair. The death of a son in 1915, the strain of the war years, during which he was frequently called upon for work on various committees, and the heavy demands on him caused by the luge influx of students after the armistice, told very heavily on his health, and in 1923 he resigned the Chair. From the date of his retiral he was a confirmed invalid, and he passed away on the 10th of October 1925. He is survived by his widow, four daughters, and three sons, one of whom, James G. Gray, is Professor of Applied Physics in Glasgow University.

His writings cover a wide field. His first book, Absolute Measurements in Electricity and Magnetism, which grew out of a series of articles in Nature, was published in 1884. Its favourable reception led to the composition of the more comprehensive treatise, The Theory and Practice of Absolute Measurements in Electricity and Magnetism, which contains more than 1400 pages, and appeared in three volumes, the first in 1888 and the others in 1893 . This book was written at a time when electrical lighting was coming into use and the need for accurate measurement was being felt. Owing to his association with Lord Kelvin, Professor Gray was able to speak with authority on the subject, and he spared himself no labour in reading original papers to make the work a well-arranged storehouse of information. It was consequently found useful by the members of the Electrical Standards Committee of the British Association and scientists all over the world, and undoubtedly did much to make experimental electricity an exact science. Some of the suggestions contained in the book as to standards and formulæ of inductance were taken up in great detail by the late Mr E. B. Rosa and his colleagues of the physical staff of the Bureau of Standards at Washington. A revised and rewritten edition of the book appeared in 1921.

The Treatise on Bessel Functions and their Applications to Physics written in collaboration with Professor G. B. Mathews, was published in 1895. The book was universally accepted as attaining the object the authors had in view, and is too well known to need any comment. A second and revised edition was brought out in 1922 by Professor Gray and Dr T. M. MacRobert. 
376 Proceedings of the Royal Society of Edinburgh. [Sess.

When occupied with The Theory and Practice of Absolute Measurements in Electricity and Magnetism, the idea occurred to Professor Gray of writing a systematic book on electricity. A Treatise on Magnetism and Electricity was the result. This appeared in 1898, three years after Sir Joseph Thomson's Elements of Electricity and Magnetism. It covered the same range as the latter book, but the treatment was more mathematical and much more exhaustive.

In 1901 appeared the first volume of A Treatise on Physics, which was never completed. The first volume dealt with Dynamics and Properties of Matter, and was translated into German by Professor Auerbach of Jena. In his preface the translator says, that the book is characteristically English in its style, and that there is no doubt that the treatment is concise, clear, fair, and practical-qualities in which the British physicists are considered to excel. It is unfortunate that more time was not given to this project. We possess no book in English similar to Chwolson's Physics; and Professor Gray, with his great knowledge, balance, good literary style, and wide appeal, was pre-eminently the man to write one.

In 1911 appeared $A$ Treatise on Dynamics, written in conjunction with his son Dr J. G. Gray; and in 1919 appeared the monumental Gyrostatics and Rotational Motion, the fullest treatment of this subject in any language. The subject was one that interested Professor Gray all his life; an interest that grew with the development of his son's models and his inventions during the war, and Professor Gray's knowledge of the equations involved became latterly almost intuitive. He visualised the angular momenta growing up in the different directions, even in the most complicated cases, and knew what the results were going to be, long before they were brought out by the analysis.

The work that he will be principally remembered for was his teaching and the reorganisation of the Natural Philosophy Department in the University of Glasgow. When he came to Glasgow from Bangor he found a department, the equipment of which had been allowed to fall behind the times, and laboratory classes of a couple of dozen students per year. Those who were with him during these first years remember how the appearance of the place altered visibly from week to week, and how the laboratory classes overflowed into attics and into the rooms under the tower, and the energy he put into the plans for the new Natural Philosophy Institute. As a result of his efforts the latter was opened in 1906. It is the largest building devoted to the teaching of physics in the country; and the classes in it grew steadily in numbers with the 
years, until at the time of his resignation, including arts, pure science, and the various branches of applied science, there were 600 or 700 students taking laboratory courses each year.

As a teacher he had rather a contempt for the narrow academic outlook. The courses had to be in touch with practical life. He exacted solid work from his students. Reproduction of bookwork never sufficed, but always some capacity had to be shown for attacking unfamiliar problems. As head of a department he was careful, far-seeing, and always full of encouragement to the advanced students and the younger members of his staff. $\mathrm{He}$ at times expressed his condemnation of men and things he disapproved of with a vigour that made those unacquainted with him think he might be difficult to work with. But such a conception was quite wrong. He never at any time indulged in recrimination, was always big enough to accept responsibility for the mistakes of others, and it was difficult sometimes to prevail on him to visit delinquents with the penalty of their sins, even when such action was necessary in the interests of discipline.

G. A. G.

R. A.' H. 